\title{
Exploring Students' Cultural Competence Development During a Short-term International Experience: A Q-Sort Study
}

\author{
S. Rampold ${ }^{1}$, B. Coleman ${ }^{2}$, J. Bunch ${ }^{3}$, R. Roberts ${ }^{4}$
}

\section{Abstract}

This study was conducted to understand how agricultural students' cultural awareness, knowledge, sensitivity, and communication abilities combine to influence their development of cultural competence. Future graduates must have the cultural competencies needed to work effectively in cross-cultural settings. $Q$ methodology $(Q)$ was used to capture the subjectivity and lived experiences of 10 participants of a short-term international experience (IE) program. When viewed through the lens of the Personal Cultural Competence Enhancement Framework (PCCEF), findings suggested students' cultural competence development could be interpreted through three typologies: (a) Cultural Learners, (b) Cultural Engagers, and (c) Cultural Samplers. Cultural Leaner students demonstrated new awareness of their limited amount of cultural knowledge and desired to learn more about other cultures through future travel. Cultural Engagers, on the other hand, expressed greater confidence in stepping out of their comfort zones to engage and communicate in diverse settings. Cultural Samplers demonstrated increased awareness of the benefits of experiencing other cultures and expressed a desire to continue traveling abroad in the future but were not highly motivated to engage fully with those cultures. These findings support the use of short-term IE programs as supplemental activities to foster agricultural students' progression toward cultural competence. Examining the typologies of study abroad participants can help demonstrate how students' study abroad experiences uniquely combine to shape their progression toward cultural competence development and be used to inform the development of future IE programs that foster such development.

\section{Keywords}

Personal Cultural Competence Enhancement Framework; Q Methodology; Study Abroad Impacts; Undergraduate Students.

1. Shelli D. Rampold, Research Coordinator, UF/IFAS Center for Public Issues Education in Agriculture and Natural Resources, University of Florida, 1408 Sable Palm Dr., Gainesville, FL 32611, srampold@ufl.edu, http://orcid.org/0000-0003-4815$\underline{7157}$

2. Bradley M. Coleman, Doctoral Graduate Assistant, Department of Agricultural Education and Communication, University of Florida, 310 Rolfs Hall, Gainesville, FL 32611-0540, bradleycoleman@ufl.edu, https://orcid.org/0000-0001-5981-5747

3. J.C. Bunch, Associate Professor, Department of Agricultural Education and Communication, University of Florida, PO Box 110540, 307C Rolfs Hall, Gainesville, FL 32611, bunchj@ufl.edu, https://orcid.org/0000-0001-8729-2349

4. Richie Roberts, Assistant Professor, Department of Agricultural and Extension Education and Evaluation, Louisiana State University, 131 J.C. Miller Hall, Baton Rouge, LA, 70803; roberts3@lsu.edu, https://orcid.org/0000-0002-2993-4945 


\section{Introduction and Problem Statement}

The internationalization of higher education has increased over the past three decades (Bedenlier et al., 2017; Deardorff, 2006; Deardorff et al., 2012; de Wit, 2020; Mitchell \& Neilsen, 2012). In response, de Wit (2020) called for greater examination of the educational, research, and societal implications of internationalization efforts at the post-secondary level. A key outcome of purposeful internationalization in higher education is the ability to produce more culturally competent graduates entering the workforce in a world that is more globally connected (Deardorff, 2006). Although no universal definition of cultural competence exists, it has been broadly defined as the ability to think and interact appropriately and effectively across cultural settings (Deardorff, 2011; Hammer et al., 2003). One common strategy used to actualize goals for developing cultural competence is engaging faculty and students in international experiences (Byker \& Putnam, 2019). Much research has been conducted to explore best methods of doing so (Bunch et al., 2015; Danjean et al., 2015; Rampold et al., 2018).

Study abroad courses and short-term international experience (IE) programs provide relatively accessible opportunities that have been shown to yield desirable outcomes among participants (Bunch et al., 2018; Dietz \& Baker, 2018; Harris et al., 2018; Zamastil-Vondrova, 2005). However, to ensure these high-impact practices instill cultural competence in students more systematically, continuous, and rigorous assessment and evaluation of programmatic impacts are warranted (Russell \& Morris, 2008). Existing evidence has demonstrated that impact assessments of study abroad courses and IE programs vary considerably based on intensity, context, lived experiences, and subjectivity of program participants (Bunch et al., 2018; Dietz \& Baker, 2018; Pigg et al., 2020; Roberts \& Edwards, 2016; Salisbury et al., 2013). To understand better the development of cultural competence, it is critical to describe how students' awareness, knowledge, sensitivity, and skills, combine to influence their development of cultural competence as a result of IE programs (Bunch et al., 2018; Russel \& Morris, 2008).

\section{Theoretical and Conceptual Framework}

The personal cultural competence enhancement framework (PCCEF) served as the conceptual framework for this study (Bunch et al., 2018). Per the PCCEF, cultural competence requires the development of cultural awareness, cultural understanding (i.e., cultural knowledge and sensitivity), and cultural communication (see Figure 1). Cultural awareness does not require indepth knowledge of another culture or country, but rather is a preliminary step in the development of cultural competence that may result from mere exposure of another culture (Perry \& Southwell, 2011). In this respect, cultural awareness involves the transition from a mecentered to an others-centered analysis, in which individuals begin to evaluate their own beliefs, values, and customs as they being to relate to those of other individuals (Bunch et al., 2018).

Cultural understanding comprises the domains of cultural knowledge and sensitivity. Cultural knowledge is the cognitive domain of cultural understanding that pertains to gains in knowledge of another culture and the differences between that culture and one's own. An individual's subjective response to and experience of such differences represents cultural 
sensitivity, the affective domain of cultural understanding (Bennett, 1993; Bunch et al., 2018; Hammer et al., 2003).

Lastly, cultural communication describes an individual's ability and willingness to effectively and appropriately communicate with people from cultures different than their own. Whether viewed as an individual attribute or a characteristic of the relational or situational context, successful cultural communication requires an understanding and tolerance of cultural differences and the ability to overcome those differences when engaging with people of another culture (Bunch et al., 2018; Clarke et al., 2009; Perry \& Southwell, 2011; see Figure 1). 


\section{Figure 1}

\section{Personal Cultural Competence Enhancement Framework}

\section{Input Process Output}

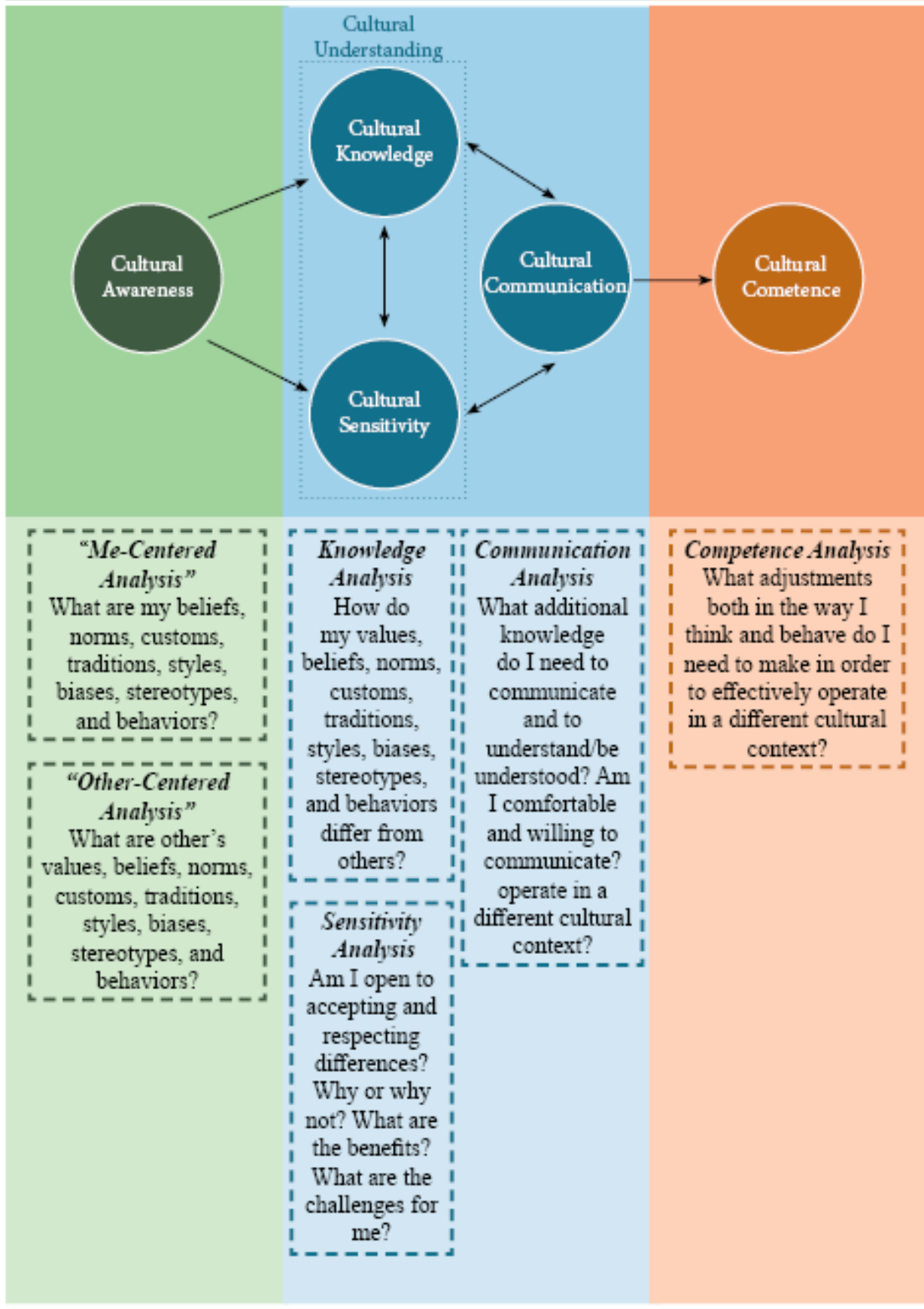

Note. Reprinted from "The Impact of a Short-Term International Experience on Undergraduate Students' Cultural Competency" by J. C. Bunch, S. D. Rampold, M. Cater, and J. J. Blackburn, 2018, Journal of Agricultural Education, 59(4), p. 132. (https://doi.org10.5032/jae.2018.04120). 


\section{Purpose}

Participants in this study included ten undergraduate students who enrolled in a short-term agricultural IE program to Costa Rica. The purpose of this study was to understand how students' cultural awareness, knowledge, sensitivity, and communication abilities combine in their progression toward cultural competence following their participation in a short-term IE program. The following research question guided this investigation: How do students' experiences during a short-term international experience contribute to their progression toward cultural competence?

\section{Methods}

Q methodology (Q) was used to capture the subjectivity and lived experiences of IE program participants and assess the impact the program had on their cultural competence development. The participants in this study were 10 undergraduate students who enrolled in a short-term IE in Costa Rica during the 2019 spring semester break. Q involves a unique data collection technique, called a Q-sort, that utilizes both quantitative and qualitative approaches to understand the collective views of individuals on a phenomenon of interest (Watts \& Stenner, 2013). This method is appropriate for small sample sizes (McKeown \& Thomas, 2013) as the emphasis is placed on capturing subjective perspectives of participants in a moment-in-time, rather than on generalizing outcomes (Brown, 1980; Watts \& Stenner, 2013). To facilitate such, researchers (a) develop a concourse, (b) create a Q-set, (c) recruit participants to collect data through a Q-sort, and (d) use factor analysis and naturalistic analytic procedures to interpret emergent findings.

The concourse is the full range of perspectives that exist on a phenomenon in the form of a collection of statements (Brown, 1993; Paige \& Morin, 2016). The concourse can be generated using relevant theories, literature, qualitative data, or a combination of both (Brown, 1993; Paige \& Morin, 2016; Watts \& Stenner, 2005). In this study, the concourse was constructed using prior literature (Sæbjørnsen et al., 2016) and journal entries and daily group reflections from the IE program participants. Through this strategy, 235 initial statements were collected to represent this study's concourse.

A subset of statements was then drawn from the concourse to create the $Q$-set. Statements included in the Q-set are sampled to represent the population (Paige \& Morin, 2016; Watts \& Stenner, 2005). An a priori theoretical framework was utilized in this study to structure the $Q$ set by which the four antecedents of cultural competence outlined in the PCCEF were used: (a) cultural awareness; (b) cultural sensitivity; (c) cultural knowledge; and (d) cultural communication (Bunch et al., 2018). Homogeneity within each conceptual category and heterogeneity between categories were pursued when negotiating statements for inclusion. This process resulted in 36 statements, with nine statements in each of the PCCEF conceptual categories. 
The ten IE program participants, or P-set in Q methodology, then engaged in the Q-sort activity. Each participant was provided a packet of the 36 statements and asked to sort the statements into three categories: (1) most like me, (2) most unlike me, and (3) neutral (McKeown \& Thomas, 2013). Participants then self-sorted the statements on a forced distribution board in ranking order of personal preference from -4 (most unlike me) to +4 (most like me) using the condition of instruction: How have you changed as a result of your experiences gained during the international program in Costa Rica? The condition of instruction is not intended to be the stem of a response scale, but rather provides participants instruction on how to approach the sort. For example, students who previously had a desire to travel abroad, but did not gain more desire to do so as a direct result of the Costa Rica IE program, may not place that statement in the "most like me" category. The condition of instruction used for this study was selected to best examine student outcomes that were a direct result of the Costa Rica IE. An explanation of the condition of instruction was provided to all participants prior to the Q-sort activity. Compared to conventional research methodologies, validity and reliability are of relatively less concern (Brown, 1980). In Q, emphasis is instead placed on replication under a similar condition of instruction to examine whether similar factors emerge (Brown, 1980; McKeown \& Thomas, 2013). For instance, the condition of instruction in this study served to specify competencies gained because of the IE program and, not other life experiences of the participants.

Participants' sorts were uploaded to PQ Method ${ }^{\circledR}$ version 2.35 (Schmolck, 2014), and three statistical tests were performed: correlation, principal components factor analysis, and computation of factor scores. Unlike traditional factor analysis that correlates items in an instrument, $Q$ correlates individual sorters, rather than individual items as in traditional quantitative methodology (Brown, 1980). Using Varimax rotation, a three-factor solution was chosen with a base significance of .52 that captured 10 participants and $61 \%$ of the total variance. Correlations among factors were negligible, meaning each factor was considered unique. Factors were interpreted by investigating factor array positions, factor loadings, distinguishing and consensus statements, and participants' personal characteristics (Mauldin, 2012).

\section{Findings}

To identify defining sorts, the factor matrix (see Table 1) was analyzed by establishing a base significance of 0.52 . Defining sorts are those that load high (significantly) and pure on only one factor. The sorts of all 10 participants were considered defining. 
Table 1

Factor Matrix with Demographics of Participants

\begin{tabular}{|c|c|c|c|c|c|}
\hline \multirow{2}{*}{$\begin{array}{l}\text { P Number/ } \\
\text { Gender }\end{array}$} & \multirow[t]{2}{*}{ Age } & \multirow[t]{2}{*}{ Academic Department } & \multicolumn{3}{|c|}{ Factor Loadings } \\
\hline & & & 1 & 2 & 3 \\
\hline 1-female & 19 & $\begin{array}{l}\text { Agricultural Education and } \\
\text { Communication }\end{array}$ & .12 & $.67^{\mathrm{b}}$ & .34 \\
\hline 2-female & 20 & $\begin{array}{l}\text { Agricultural Education and } \\
\text { Communication }\end{array}$ & $.52^{\mathrm{a}}$ & -.18 & .46 \\
\hline 3-female & 19 & $\begin{array}{l}\text { Agricultural Education and } \\
\text { Communication }\end{array}$ & $.78^{\mathrm{a}}$ & .17 & .31 \\
\hline 4-female & 22 & $\begin{array}{l}\text { Agricultural Education and } \\
\text { Communication }\end{array}$ & $.81^{\mathrm{a}}$ & .21 & -.02 \\
\hline 5-female & 22 & $\begin{array}{l}\text { Agricultural Education and } \\
\text { Communication }\end{array}$ & -.05 & -.03 & $.88^{\mathrm{c}}$ \\
\hline 6-female & 20 & Animal Sciences & -.02 & $.89^{b}$ & .00 \\
\hline 7-female & 19 & $\begin{array}{l}\text { Agricultural Education and } \\
\text { Communication }\end{array}$ & .03 & .37 & $.65^{c}$ \\
\hline 8-female & 63 & $\begin{array}{l}\text { Agricultural Education and } \\
\text { Communication }\end{array}$ & .16 & $.52^{b}$ & -.05 \\
\hline 9-male & 19 & Food and Resource Economics & $.83^{\mathrm{a}}$ & .11 & .01 \\
\hline 10-male & 20 & $\begin{array}{l}\text { Agricultural Education and } \\
\text { Communication }\end{array}$ & .29 & .01 & $.57^{c}$ \\
\hline Defining Sor & & & 4 & 3 & 4 \\
\hline$\%$ Variance $\mathrm{E}$ & lained & & $24 \%$ & $18 \%$ & $19 \%$ \\
\hline
\end{tabular}

Note. P Number refers to the numeric identifier for each participant.

andicates a defining sort for Factor 1. ' Indicates a defining sort for Factor 2. 'Indicates a defining sort for Factor 3.

Analysis of the data yielded three factors: (1) Cultural Learners; (2) Cultural Engagers; and (3) Cultural Samplers. Four participants, one male, and three females, loaded significantly as Cultural Learners (see Table 2). Many of these students had not previously traveled on their own, and they demonstrated new awareness of the cultural knowledge they were lacking and a desire to learn more about other cultures. From their perspectives, the IE gave them a greater desire to travel abroad $(35,+4)$ and willingness to pursue international agricultural opportunities $(28,+4)$. They also felt the IE helped them grow as a culturally minded individual $(21,+3)$. In a follow-up interview, one student noted, "I realized how much I still need to learn about other cultures." Similarly, another student said, "I feel like I'm not very aware of other cultures, because I just live in my own little bubble. So, going to Costa Rica made me more aware of the differences in cultures and how other people live." Although these students had gained some confidence in their abilities to travel, they were still fairly apprehensive about engaging fully in culturally diverse settings and trying to communicate in another language (31, -4; see Table 2). 
Table 2

Array Positions for Cultural Learner Students' Statements

\begin{tabular}{|c|c|c|c|c|}
\hline No. & Statement & Array Position & $z$-score & Theoretical Category \\
\hline $28^{a}$ & $\begin{array}{l}\text { I am more willing to pursue international } \\
\text { agriculture opportunities. }\end{array}$ & +4 & 1.89 & Cultural Communication \\
\hline 35 & I have a greater desire to travel abroad. & +4 & 1.82 & Cultural Communication \\
\hline 32 & $\begin{array}{l}\text { I have a greater desire to learn Spanish (or } \\
\text { another language). }\end{array}$ & +3 & 1.22 & Cultural Communication \\
\hline 22 & $\begin{array}{l}\text { I am more aware of the benefits of } \\
\text { experiencing other cultures. }\end{array}$ & +3 & 1.56 & Cultural Sensitivity \\
\hline 21 & $\begin{array}{l}\text { I have grown as a culturally mindful } \\
\text { individual. }\end{array}$ & +3 & 1.33 & Cultural Sensitivity \\
\hline 7 & $\begin{array}{l}\text { I am more aware of the comforts I have at } \\
\text { home. }\end{array}$ & +3 & .91 & Cultural Awareness \\
\hline $14^{\mathrm{a}}$ & $\begin{array}{l}\text { I am more knowledgeable of the } \\
\text { differences in values between US and } \\
\text { CR cultures. }\end{array}$ & -3 & -1.32 & Cultural Knowledge \\
\hline $10^{\mathrm{a}}$ & $\begin{array}{l}\text { I am better able to make comparisons } \\
\text { between other cultures. }\end{array}$ & -3 & -1.24 & Cultural Knowledge \\
\hline 4 & I am more aware of my own traditions. & -3 & -1.24 & Cultural Awareness \\
\hline $1^{\mathrm{a}}$ & $\begin{array}{l}\text { I am more aware of the cultural values in } \\
\text { Costa Rica. }\end{array}$ & -3 & -1.40 & Cultural Awareness \\
\hline 33 & $\begin{array}{l}\text { I am more comfortable trying to } \\
\text { communicate in another language. }\end{array}$ & -4 & -1.46 & Cultural Communication \\
\hline 31 & $\begin{array}{l}\text { I am more comfortable using foreign } \\
\text { currency }\end{array}$ & -4 & -2.04 & Cultural Communication \\
\hline
\end{tabular}

Cultural Engagers, which included all female participants (3/3), perceived the IE helped them feel less apprehensive about stepping out their comfort zones $(29,+4)$ and more confident in their abilities to travel abroad $(30,+4)$ by helping them feel more comfortable engaging in culturally diverse settings $(36,+3)$. One high and pure loader stated, "I'm more comfortable engaging in a culturally diverse setting. I never felt I was uncomfortable, but now I feel when I talk to my friends about someone [from another background] I can have more patience and think about where they come from and why they think like that." Cultural Engagers also expressed a greater desire to learn another language $(32,+3)$ and a higher degree of comfortability to communicate in another language $(33,+3)$. However, cultural engagers did not perceive the IE helped them become more aware of the stereotypes they hold toward other cultures $(8,-4)$, helped them become more knowledgeable of the differences between U.S. and Costa Rican cultures $(11,-3)$, nor help them become more aware of the challenges they 
face in being respectful of other cultures (23, -3 ; see Table 3$)$. Follow-up interviews with Cultural Engagers revealed they felt the IE was very agriculturally based and helped them learn more about agricultural production topics than cultural traditions. One participant stated, "anything that had to do with tradition I immediately put to the left because I felt like, in my experience there, I didn't experience many traditional things."

\section{Table 3}

Array Positions for Cultural Engager Students' Statements

\begin{tabular}{|c|c|c|c|c|}
\hline No. & Statement & Array Position & $z$-score & Theoretical Category \\
\hline 30 & $\begin{array}{l}\text { I feel more confident in my ability to travel } \\
\text { abroad. }\end{array}$ & +4 & 1.77 & Cultural Communication \\
\hline 29 & $\begin{array}{l}\text { I am less apprehensive about leaving my } \\
\text { comfort zone. }\end{array}$ & +4 & 1.59 & Cultural Communication \\
\hline $36^{\mathrm{a}}$ & $\begin{array}{l}\text { I am more comfortable engaging in } \\
\text { culturally diverse settings. }\end{array}$ & +3 & 1.37 & Cultural Communication \\
\hline 21 & $\begin{array}{l}\text { I have grown as a culturally mindful } \\
\text { individual. }\end{array}$ & +3 & 1.45 & Cultural Sensitivity \\
\hline $33^{\mathrm{a}}$ & $\begin{array}{l}\text { I am more comfortable trying to } \\
\text { communicate in another language. }\end{array}$ & +3 & 1.42 & Cultural Communication \\
\hline 32 & $\begin{array}{l}\text { I have a greater desire to learn Spanish (or } \\
\text { another language). }\end{array}$ & +3 & 1.36 & Cultural Communication \\
\hline 3 & $\begin{array}{l}\text { I am more aware of my own values and } \\
\text { beliefs. }\end{array}$ & -3 & -1.56 & Cultural Awareness \\
\hline 11 & $\begin{array}{l}\text { I am more knowledgeable of the } \\
\text { differences in traditions between US } \\
\text { and CR cultures. }\end{array}$ & -3 & -1.92 & Cultural Knowledge \\
\hline 23 & $\begin{array}{l}\text { I am more aware of the challenges I face in } \\
\text { being respectful of other cultures. }\end{array}$ & -3 & -1.33 & Cultural Sensitivity \\
\hline 13 & $\begin{array}{l}\text { I am more knowledgeable of the } \\
\text { similarities in traditions between US } \\
\text { and CR cultures. }\end{array}$ & -3 & -1.39 & Cultural Knowledge \\
\hline $8^{a}$ & $\begin{array}{l}\text { I am more aware of the stereotypes I hold } \\
\text { toward other cultures. }\end{array}$ & -4 & -1.83 & Cultural Awareness \\
\hline 4 & I am more aware of my own traditions. & -4 & -1.99 & Cultural Awareness \\
\hline
\end{tabular}

Note. The No. column provides the reference number for each statement in the q-set.

andicates distinguishing statements for the Cultural Engager Students typology.

Cultural Samplers included three participants, one male, and two females. From their perspectives, the IE inspired them to travel abroad $(35,+4)$ again in the future, and helped them build confidence in their abilities to study abroad $(30,+4)$. The IE also enhanced their awareness of the benefits of experiencing other cultures $(22,+3)$, as well as their awareness of the comforts they have back home $(7,+3)$. However, the IE did not facilitate a greater desire to learn another language $(32,-4)$, nor did it help them feel more comfortable to communicate in 
another language $(33,-3)$. For example, one student maintained, "I'm definitely not comfortable at all trying to communicate in any language other than English. While [in Costa Rica], I really struggled with that and I have not changed at all." Further, their experiences abroad did not change Cultural Sampler students' degree of awareness of the challenges they face in being accepting $(25,-3)$ and respectful $(23,-3)$ of other cultures. Cultural Samplers' significant statements are displayed in Table 4.

Table 4

Array Positions for Cultural Sampler Students' Statements

\begin{tabular}{|c|c|c|c|c|}
\hline No. & Statement & Array Position & $z$-score & Theoretical Category \\
\hline 35 & I have a greater desire to travel abroad. & +4 & 1.74 & Cultural Communication \\
\hline 30 & $\begin{array}{l}\text { I feel more confident in my ability to travel } \\
\text { abroad. }\end{array}$ & +4 & 1.56 & Cultural Communication \\
\hline 22 & $\begin{array}{l}\text { I am more aware of the benefits of } \\
\text { experiencing other cultures. }\end{array}$ & +3 & 1.50 & Cultural Sensitivity \\
\hline 7 & $\begin{array}{l}\text { I am more aware of the comforts I have at } \\
\text { home. }\end{array}$ & +3 & 1.43 & Cultural Awareness \\
\hline 16 & $\begin{array}{l}\text { I am better able to relate everyday } \\
\text { experiences to my international } \\
\text { experiences and make sense of them. }\end{array}$ & +3 & 1.23 & Cultural Knowledge \\
\hline 27 & $\begin{array}{l}\text { I am more patient when working with } \\
\text { people from other cultures. }\end{array}$ & +3 & .98 & Cultural Sensitivity \\
\hline 33 & $\begin{array}{l}\text { I am more comfortable trying to } \\
\text { communicate in another language. }\end{array}$ & -3 & -1.21 & Cultural Communication \\
\hline 25 & $\begin{array}{l}\text { I am more aware of the challenges I face in } \\
\text { being accepting of other cultures. }\end{array}$ & -3 & -1.26 & Cultural Sensitivity \\
\hline 9 & $\begin{array}{l}\text { I am more knowledgeable of the } \\
\text { similarities in traditions between US } \\
\text { and CR cultures. }\end{array}$ & -3 & -1.30 & Cultural Knowledge \\
\hline 23 & $\begin{array}{l}\text { I am more aware of the challenges I face in } \\
\text { being respectful of other cultures. }\end{array}$ & -3 & -1.48 & Cultural Sensitivity \\
\hline 31 & $\begin{array}{l}\text { I am more comfortable using foreign } \\
\text { currency. }\end{array}$ & -4 & -1.86 & Cultural Communication \\
\hline $32^{\mathrm{a}}$ & $\begin{array}{l}\text { I have a greater desire to learn Spanish (or } \\
\text { another language). }\end{array}$ & -4 & -1.93 & Cultural Communication \\
\hline
\end{tabular}

Note. The No. column provides the reference number for each statement in the q-set.

andicates distinguishing statements for the Cultural Sampler Students typology.

\section{Conclusions, Discussion, and Recommendations}

Overall, the findings of this study support the continued use of short-term programs to help generate cultural competency outcomes among agricultural undergraduate students. When viewed through the lens of the PCCEF (Bunch et al., 2018), students' cultural competence was interpreted through three perspectives: (a) Cultural Learners, (b) Cultural Engagers, and (c) Cultural Samplers. Cultural Learners perceived the IE instilled in them a greater desire to travel abroad and pursue international agriculture 
opportunities. The IE also helped enhanced their awareness of the cultural knowledge they did not possess. In follow-up interviews after the sort activity, students in this typology explained that the IE made them more aware of their general lack of cultural knowledge about Costa Rica and other cultures. These conclusions align with the notions of cultural awareness described by Bunch et al. (2018) and suggest these students are in the early stages of their cultural competence development. Cultural Engagers reported the IE lowered their apprehension about leaving their comfort zones, as well as helped them become more self-assured in their abilities to travel abroad and engage in culturally diverse settings. These participants felt more comfortable trying to communicate in another language and expressed a greater desire to learn another language. Growth among these students was primarily in areas of the cultural communication element of the PCCEF (Bunch et al., 2018) and suggest more advanced cultural competence development than any of the other typologies observed. Cultural Samplers expressed the IE promoted a greater desire to travel abroad and confidence in their abilities to do so. However, post Q-sort interviews with Cultural Samplers suggested these students have an interest in experiencing, or "sampling," many new cultures to push themselves out of their comfort zones, but little motivation to engage fully in those cultures. The IE also did not help these students become more aware of the challenges they face in being accepting and respectful of other cultures. Per the PCCEF (Bunch et al., 2018), students in this typology appeared to still be developing in all elements. However, it should be noted that some students in this typology had already acquired extensive international experience prior to the IE program. The retrospective design of the study is a limitation in that students' prior experience likely contributed to patterns in the findings related to awareness of challenges faced in being accepting and respectful of other cultures, because some of students may have already developed such abilities. Future research is needed to examine how IE programs impact students with and without prior international experience.

It is recommended that those seeking to implement short-term IE programs as a means of internationalizing higher education should include opportunities for students to increase their cultural competence. While the design of the Costa Rica IE helped students gain agricultural production knowledge, the findings suggest more activities focused on cultural traditions need to be included in IE programs to foster cultural competence development. Doing so aligns with de Wit's (2020) pillars of purposeful internationalization by building abilities to learn about and engage with other cultures. Providing students experiences in which they can build knowledge of cultural beliefs, customs, traditions and stereotypes, build sensitivity and respect toward others who are culturally different, and develop a willingness to communicate and interact with those of different cultures are all means of increasing cultural competence (Bunch et al., 2018). It is further recommended that those seeking to provide such experiences should assess program impacts with cultural competence elements found within frameworks such as the PCCEF (Bunch et al., 2018).

Further exploration of the PCCEF (Bunch et al., 2018) is needed. For most participants, statements in the cultural communication domain were split on the sort board as those most like and most unlike them. This divergence in statements could indicate that cultural communication should be expanded into two separate elements; one intended to capture attitudes or willingness to engage in other cultures (e.g., I am more comfortable engaging in culturally diverse settings); and another to capture desire or intent to verbally communicate (e.g., I have a greater desire to learn Spanish, or I am more comfortable communicating in another language). Future research should further explore cultural communication measures. As previously noted, participants of this study identified with one of three 
typologies. Further research should be conducted to identify extraneous variables (i.e., personal characteristics, previous international/domestic experience) and IE program characteristics that may have influenced students' sorting patterns. These external factors were not assessed, and the lack of ability to control for such was a limitation of this study. Lastly, Q research should be conducted with participants of other short-term IE programs to compare results and help identify program designs or characteristics most useful in facilitating cultural competencies.

\section{References}

Bedenlier, S., Kondakci, Y., \& Zawacki-Richter, O. (2017). Two decades of research into the internationalization of higher education: Major themes in the Journal of Studies in Internationalization (1997-2016). Journal of Studies in International Education, 2(2), 108-135. https://doi.org/10.1177/1028315317710093

Bennet, M. J. (1993). Towards ethnorelativism: A developmental model of intercultural sensitivity. In R. M. Paige (Ed.), Education for the intercultural experience (pp. 21-71). Intercultural Press.

Brown, S. R. (1980). Political subjectivity: Applications of Q methodology in political science. Yale University Press.

Brown, S. R. (1993). A primer on Q methodology. Operant Subjectivity, 16(3/4), 91-138. https://doi.org/10.15133/i.os.1993.002

Bunch, J. C., Blackburn, J. J., Danjean, S. E., Stair, K. E., \& Blanchard, L. D. (2015). Examining Louisiana State University College of Agriculture students' perceived motivators and barriers to participation in international experiences. Journal of International Agricultural and Extension Education, 22(3), 69-82. https://doi.org/10.5191/jiaee.2015.22305

Bunch, J. C., Rampold, S. D., Cater, M., \& Blackburn, J. J. (2018). The impact of a short-term international experience on undergraduate students' cultural competency. Journal of Agricultural Education, 59(4), 120-136. https://doi.org10.5032/jae.2018.04120

Byker, E. J., \& Putman, S. M. (2019). Catalyzing cultural and global competencies: Engaging preservice teachers in study abroad to expand the agency of citizenship. Journal of Studies in International Education, 23(1), 84-105. https://doi.org/10.1177/1028315318814559

Clarke, I., Flaherty, T. B., Wright, N. D., \& McMillen, R. M. (2009). Student intercultural proficiency from study abroad programs. Journal of Marketing Education, 31(2), 173181. https://doi.org/10.1177/0273475309335583

Danjean, S. E., Bunch, J. C., \& Blackburn, J. J. (2015). Examining the motivations and barriers influencing the decisions of Louisiana State University College of Agriculture freshmen to participate in international experiences. Journal of International Agricultural and Extension Education, 22(1), 49-62. https://doi.org/10.5191/jiaee.2015.22104 
Dietz, S. S., \& Baker, S. B. (2018). Study abroad as a cultural competence development tool: Case study Honduras. Journal for the Advancement of Counselling, 41(1), 104-124. https://doi.org/10.1007/s10447-018-9348-9

Deardorff, D. K. (2006). Identification and assessment of intercultural competence as a student outcome of internationalization. Journal of Studies in International Education, 10(3), 241-266. https://doi.org/10.1177/1028315306287002

Deardorff, D. K. (2011). Assessing intercultural competence. New Directions for Institutional Research, 149, 65-79. https://doi.org/10.1002/ir.381

Deardorff, D., de Wit, H., Heyl, J., \& Adams, T. (2012). SAGE handbook of international higher Education. Sage.

de Wit, H. (2020). Internationalization of higher education. Journal of International Students, 10(1), i-iv. https://doi.org/10.32674/jis.v10i1.1893

Hammer, M. R., Bennett, M. J., \& Wiseman, R. (2003). Measuring intercultural sensitivity: The intercultural development inventory. International Journal of Intercultural Relations, 27, 421-443. https://doi.org/10.1016/S0147-1767(03)00032-4

Harris, V. W., Kumaran, M., Harris, H. J., Moen, D., \& Visconti, B. (2018). Assessing multicultural competence (knowledge and awareness) in study abroad experiences. Compare: A Journal of Comparative and International Education, 49(3), 430-452. https://doi.org/10.1080/03057925.2017.1421901

Mauldin, C. (2012). Overview of the $Q$ interpretation process. Media Marketing Inc.

McKeown, B., \& Thomas, D. (2013). Q methodology (2nd ed.). Sage.

Mitchell, D. E., \& Nielsen, S. Y. (2012). Internationalization and globalization in higher education. In H. Cuadra-Montiel (Ed.), Globalization-education and management agendas (pp. 3-22). InTech. https://doi.org/10.57772/48702

Paige, J. B., \& Morin, K. H. (2016). Q-sample construction: A critical step for a q-methodological study. Western Journal of Nursing Research, 38(1), 96-110. https://doi.org/10.1177/0193945914545177

Perry, L. B., \& Southwell, L. (2011). Developing intercultural understanding and skills: Models and approaches. Intercultural Education, 22(6), 453-466. https://doi.org/10.1080/14675986.2011.644948

Pigg, J., Richardson, M. A., Roberts, R., \& Stair, K. S. (2020, May 18-21). Awakening transformative learning: A comparison of the dissonance experienced by agriculture majors during study abroad courses to Costa Rica and Thailand [Paper presentation]. American Association for Agricultural Education (AAAE) COVID-19 Virtual Conference. http://aaaeonline.org/resources/Documents/National/2020Meeting/2020AAAEPaperPr oceedings.pdf 
Rampold, S. D., Cater, M., Bunch, J. C., \& Blackburn, J. J. (2018). Explaining agriculture faculty members' involvement in study abroad: Structural relationships among personaldimension variables. Journal of International Agricultural and Extension Education, 25(3), 51-65. https://doi.org/10.5191/jiaee.2018.25304

Roberts, R., \& Edwards, M. C. (2016). Transforming students' global knowledge and perspectives through international service learning (ISL): How U.S. university agriculture students made sense of their lived experiences over time. Journal of International Agricultural and Extension Education, 23(3), 7-22. https://doi.org/10.5191/jiaee.2016.23301

Russell, M., \& Morris, P. (2008, March 9-15). A "mixed model" for assessing intercultural and attitudinal outcomes of international service-learning experiences [Abstract presentation]. Association for International Agricultural and Extension Education (AIAEE) 24th Annual Meeting, EARTH University, Costa Rica. https://www.aiaee.org/attachments/article/684/449.pdf

Sæbjørnsen, S. E. N., Ellingsen, I. T., Good, J. M. M., \& Odegard, A. (2016). Combining a naturalistic and theoretical $Q$ sample approach: An empirical research illustration. Operant Subjectivity: The International Journal of Q Methodology, 38(2), 15-32. https://doi.org/10.15133/i.os.2016.005

Salisbury, M. H., Brian, A. P., \& Pascarella, P. T. (2013). The effect of study abroad on intercultural competence among undergraduate college students. Journal of Student Affairs Research and Practice, 50(1), 1-20. https://doi.org/10.1515/isarp-2013-0001

Schmolck, P. (2014). PQMethod manual. Author. http://schmolck.org/qmethod/downpqwin.htm

Watts, S., \& Stenner. P. (2005). Doing Q methodology: Theory, method and interpretation. Qualitative research in psychology, 2(1), 67-91. https://doi.org/10.1191/1478088705qp022oa

Watts, S., \& Stenner, P. (2013). Doing Q methodological research: Theory, method, and interpretations (2nd ed.). Sage.

Zamasti-Vondrova, K. (2005). Good faith or hard data? Justifying short-term programs. International Educator, 14(1), 44-49. https://search.proquest.com/docview/200757299?pq-origsite=gscholar

(C) 2020 by authors. This article is an open access article distributed under the terms and conditions of the Creative Commons Attribution license (http://creativecommons.org/licenses/by/4.0/). 